
Not for reproduction, distribution or commercial use.

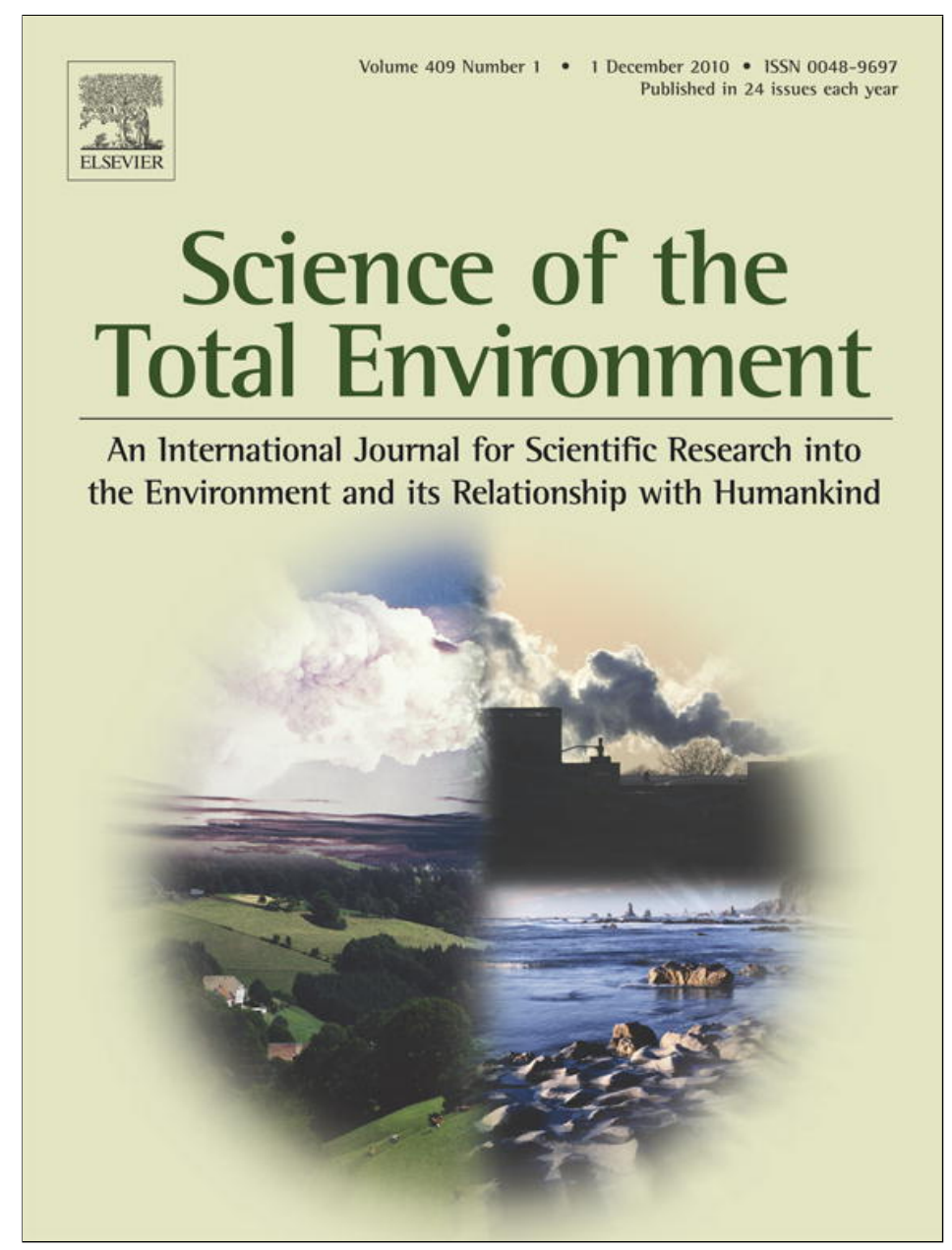

This article appeared in a journal published by Elsevier. The attached copy is furnished to the author for internal non-commercial research and education use, including for instruction at the authors institution and sharing with colleagues.

Other uses, including reproduction and distribution, or selling or licensing copies, or posting to personal, institutional or third party websites are prohibited.

In most cases authors are permitted to post their version of the article (e.g. in Word or Tex form) to their personal website or institutional repository. Authors requiring further information regarding Elsevier's archiving and manuscript policies are encouraged to visit:

http://www.elsevier.com/copyright 


\title{
A roadmap for development of sustainable E-waste management system in India
}

\author{
Sushant B. Wath *, Atul N. Vaidya, P.S. Dutt, Tapan Chakrabarti \\ National Environmental Engineering Research Institute (NEERI), Nehru Marg, Nagpur-440 020, India
}

\section{A R T I C L E I N F O}

\section{Article history:}

Received 15 July 2010

Received in revised form 8 September 2010

Accepted 18 September 2010

Available online 16 October 2010

\section{Keywords:}

Extended Producer Responsibility (EPR)

Advance Recycling Fee (ARF)

Developing countries

E-waste management

Government

\begin{abstract}
A B S T R A C T
The problem of E-waste has forced Environmental agencies of many countries to innovate, develop and adopt environmentally sound options and strategies for E-waste management, with a view to mitigate and control the ever growing threat of E-waste to the environment and human health. E-waste management is given the top priority in many developed countries, but in rapid developing countries like India, it is difficult to completely adopt or replicate the E-waste management system in developed countries due to many country specific issues viz. socio-economic conditions, lack of infrastructure, absence of appropriate legislations for Ewaste, approach and commitments of the concerned, etc. This paper presents a review and assessment of the E-waste management system of developed as well as developing countries with a special emphasis on Switzerland, which is the first country in the world to have established and implemented a formal E-waste management system and has recycled $11 \mathrm{~kg} / \mathrm{capita}$ of WEEE against the target of $4 \mathrm{~kg} / \mathrm{capita}$ set by EU. And based on the discussions of various approaches, laws, legislations, practices of different countries, a road map for the development of sustainable and effective E-waste management system in India for ensuring environment, as well as, occupational safety and health, is proposed.
\end{abstract}

(c) 2010 Elsevier B.V. All rights reserved.

\section{Introduction}

Electronics industry is the world's largest and fastest growing manufacturing industry. Rapid growth, combined with rapid product obsolescence and discarded electronics is now the fastest growing waste fraction, accounting for $8 \%$ of all municipal waste in European Union (The Economist, 2005). In developing countries, on an average it equals to $1 \%$ of total solid waste and is expected to grow to $2 \%$ by 2010 (UNEP, 2009). Electronic waste commonly known as E-waste or Waste Electrical and Electronic Equipment (WEEE), or end-of-life (EOL) electronic are the electronic appliances such as computers, laptops, TVs, DVD players, mobile phones, MP3 players etc. including their assembly, sub-assembly, components and consumables, which have been disposed of or unwanted by their original users(Bhuie et al., 2004). There is no specific definition acceptable globally, which clearly defines E-waste, as every country has its own definition for the E-waste. What to be called as the E-waste? Any electronic or electrical appliances, which are obsolete in terms of its functionality? Or is operationally discarded? Or is both? As rapid technological changes and enhancement are shortening the lifespan of the electronic products the clear definition for E-waste is needed. The most acceptable definition is of EU WEEE Directive (EU, 2003a) which defines E-waste as "Electrical or electronic equipment (EEE) which is waste including all components, sub-assemblies and consumables,

\footnotetext{
* Corresponding author. Tel./fax: +91 7122249758.

E-mail address: sb_wath@neeri.res.in (S.B. Wath).
}

which are part of the product at the time of discarding." E-waste comprises of relatively expensive and essentially durable products used for data processing, telecommunications or entertainment in private households and businesses. In this article, we use the terms "WEEE" and "E-waste" synonymously and in accordance to the EU, WEEE Directive.

The first major problem associated with E-waste management is its ever increasing quantum, and second is its scientific and environment friendly disposal, which is very critical. Fig. 1 indicates the increase in the sales of PCs in 8 years during 2001-2009 in India (MAIT, 2008-2009). According to TRAI, India added 113.26 million new cellular customers in 2008, with an average 9.5 million customers added every month. Cellular market grew from 168.11 million in 2003-2004 to 261.97 million in 2007-2008 (TRAI, 20072008). In 2006, microwave ovens and air conditioners registered a growth of about $25 \%$. Refrigerator sales amounted to 4.2 millions in 2006-2007 and its production went up by $17 \%$ as compared to the preceding year. Washing machines, which have always seen poor growth, have seen reasonable growth in 2006. The sale of colour televisions (CTVs) is increased 3 times by 2007 (NCAER, 2007).

$\mathrm{E}$-waste is the combination of both the hazardous (PBR, lead, mercury, chromium, cadmium, etc) and non-hazardous as well as precious material (gold, silver, copper, etc.) (DEFRA, 2004). The uncontrolled recycling of WEEE "backyard recycling" by the so called informal sector is the main concern in Non-OECD (Organization for Economic Co-operation and Development) countries like India, China, etc. Based on the existing evidences informal recycling is the most pressing environmental issue associated with the E-waste (Williams 
S.B. Wath et al. / Science of the Total Environment 409 (2010) 19-32

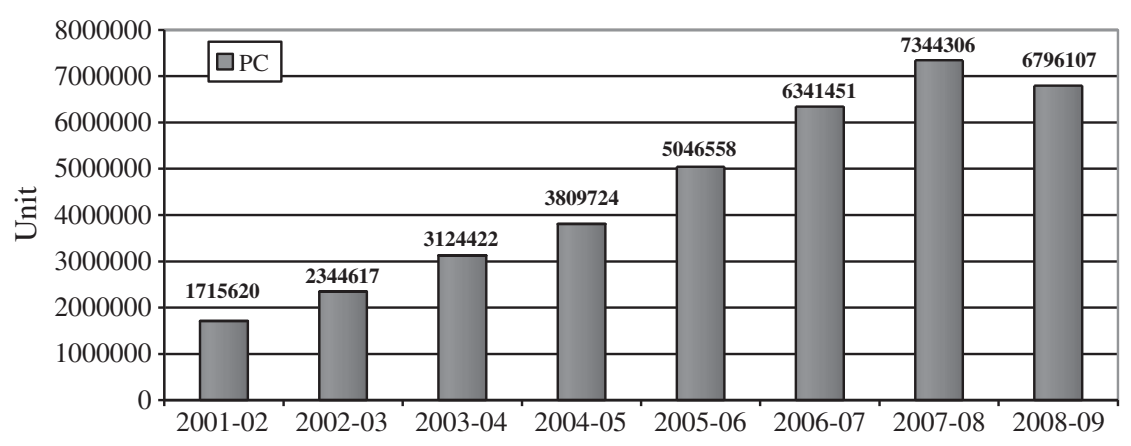

Fig. 1. Total PC (desktops and notebooks) sales: 2001-2009.

MAIT-IT Industry performance Annual Review 2008-2009.

et al., 2008). Primitive tools and methods often involve the open burning of plastic waste, exposure to toxic solders, acid baths to recover saleable materials and components from WEEE with little or no safeguards to human health and the environment which results in polluting the land, air and water due to river dumping of acids and widespread general dumping (Manomaivibool, 2009). The controlled experiments characterises very high emission factors of heavy metal, dioxins and furans (both chlorinated and brominated) in fly and residual ash from the open burning of PWBs and PVC-coated wires (Gullet et al., 2007). The impacts of informal recycling of E-waste in developing countries like India, China, etc. on human health and environment is discuss in detail in Section 4.

Managing the increasing quantum of E-waste effectively and efficiently-in terms of cost and environmental impact-is a complex task. While some countries have organized systems for the collection, segregation, recycling, disposal and monitoring, other countries are still to find a solution that ensures minimizing the negative environmental impacts of E-waste treatment and recycling. The major requirements and considerations for developing the sound Ewaste management system are:

- Special logistic requirements for collecting the E-waste from the source of its generation and transporting to the site of disposal and/ or treatment/recycling/recovery/reuse.

- E-waste contains many hazardous substances which are extremely dangerous to human health and environment, and therefore disposal requires special treatment to minimize impacts in environment.

- E-waste is a rich source of metals such as gold, silver and copper, which can be recovered and recycled/reused into the production cycle.

Our study and analysis has the following objectives; we aims to proposed a road map for the sustainable E-waste management system for India. The Section 2 reviews the current measures undertaken by developed and developing countries in terms of E-waste management, laws, regulations, policies, practices, etc. to manage the WEEE. With a special emphasis on the study of E-waste management in Switzerland (in Section 3), which ranks second in the 2010 Environmental Sustainability Index by scoring 89.1 points (http:// epi.yale.edu/Countries/Switzerland) and is also the first country in the world which has a well established formal E-waste management system (Bandyopadhyay, 2008). Also approximately 75,000 tonnes of WEEE have been collected, classified, disassembled and then processed in Switzerland in 2004 (Hischier et al., 2005), compared with the collection of approximately 68,000 tonnes in 2003 (SinhaKhetriwal et al., 2005) which corresponds to about $11 \mathrm{~kg} /$ capita and $9 \mathrm{~kg} /$ capita, recycling of E-waste, respectively. Significantly much more than the target of $4 \mathrm{~kg} /$ capita set by the European WEEE directive (EU, 2002a). Section 4 studies and discuss the E-waste scenario in India, along with the social, economical, environmental and occupational impacts of informal E-waste recycling. And also points out the positive-negative drivers and challenges of the current
E-waste system of India. In Section 5 we draw the results of the review in Sections 1, 2, 3 and 4 to briefly discuss the effectiveness and appropriateness of these results in Indian context using various approaches, practices and systems. Based on the review and discussion in previous sections, in Section 6, we propose possible new future system and technologies which takes care of approach, finances, government role and implementation issues to address multiple societal and environmental objectives regarding the E-waste in India and other developing countries.

\section{Review of E-waste regulations, laws and systems of various countries}

Many countries have understood the importance of the regulatory approach (laws and regulations) to tackle the ever increasing quantum of WEEE, and framed and formulated various laws and regulations to restrict the negative impact of WEEE on environment and occupational health (European Commission, 2000). The Table 1 gives the brief review of various regulations, rules and laws in the different countries. Switzerland: A case of well developed E-waste management system.

\section{Switzerland: A case of well developed E-waste management system}

Switzerland is the first county in the world to develop and implement the well organised and formal E-waste management system for collection, transportation, recycling/treatment and disposal of E-waste. The Fig. 2 shows the E-waste management system in Switzerland along with the material and financial flow.

The legal and operational frame work of the system is based on the Extended Producer Responsibility (EPR) model and places the physical and financial responsibilities for the environmentally sound handling, recycling and disposal of the E-waste on the manufacturer/ producer and exporter of these products. The two Producer Responsibility Organizations (PROs) - The Swiss Association for Information Communication and Organizational Technology (SWICO) and Stiftung Entsorgung Schweiz (S.E.N.S.) are responsible for the management and operations of the system on behalf of their member producers and covers different parts of WEEE, as defined by European WEEE directive (EU, 2002). Their roles and responsibilities are clearly identified and defined (Khetriwal et al., 2005).

Required finance for day to day functioning of the system (for collection, transport and recycling/disposal) is generated from visible Advance Recycling Fee (ARF), collected from all the purchaser of the new electronic appliances at the time of purchase. End consumer pays the recycling fee, which is equivalent to the difference between the total system cost and the total recovered value from the E-waste. This ensures the necessary finance needed for the system as the fees are collected in advance. It prevents the illegal disposal of E-waste as 
Table 1

Review of WEEE laws and regulation in different countries.

\begin{tabular}{ll}
\hline Laws and regulations & Major content \\
\hline $\begin{array}{l}\text { Canada }{ }^{1} \\
\begin{array}{l}\text { National stewardship principles of electronics } \\
\text { products. }\end{array}\end{array}$ & $\begin{array}{l}\text { - Includes product mixes, consumer access, designation of the responsible } \\
\text { parties, performance targets and recycling standards. Its objectives are to help, Environment (CCME) adopted in } \\
\text { develop and deliver WEEE programmes in each Canadian province and } \\
\text { territory, ensuring balance between environmental and economic } \\
\text { consideration. }\end{array}$
\end{tabular}

People's Republic of China ${ }^{2}$

- Law on the prevention of environmental pollution from solid waste (SEPA).

- Notification on the import of the seventh category of wastes (SEPA).

- Notice on strengthening the environmental management of WEEE (SEPA)

- Ordinance on the management of waste household electrical and electronic products recycling and disposal (NDRC).

- Management measure for the prevention of pollution from electronic products (MII).

- Regulation for the management of the recycling and disposal of waste electrical and electronic products (China WEEE).

European Union $(E U)^{3}$

-Waste Electrical and Electronic Equipment (WEEE) Directives (2002/96/EC) (EU 2002a).

- Restriction of Use of Certain Hazardous Substances in Electrical and Electronic Equipment Regulations (RoHS) directives (EU 2002b).

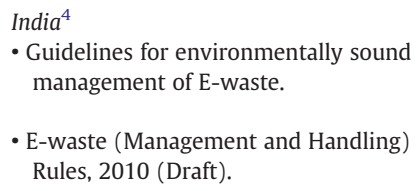

Japan $^{5}$

- The law for recycling of specified kinds of home appliances (Home Appliances Recycling Law).

- The law for promotion of the effective utilization of resources.

Philippines $^{6}$

- The law on Ecological Solid

Waste Management Act of 2000.
- Disposal of municipal and industrial solid waste; use of solid wastes as raw • Effective from April 1, 1996. materials.

- Ban on the import of the seventh category of waste.

- Effective from February 1, 2000

-WEEE processing to meet the requirements of the "Law on the prevention of • Issued August 26, 2003. environmental pollution from solid waste"; generation of WEEE to be reported to local EPBs.

- Mandatory recycling of WEEE, based on extended producer responsibility; Incorporated in the 2006 legislation certification for second hand appliances, and recycling enterprises.

plan of the state council.

- Restrictions on the use of hazardous substances (RoHS); 'green' product • Issued early 2006; will be enforced design; provision of information on the components, hazardous substances, since March 1, 2007 and recycling.

- Complements China's RoHS, 2006 and establish the regulatory regime for the • State council released the official recovery, recycling and disposal of electronic and electrical products. Covered document to the public on products will be listed in a catalogue for the disposal of discarded electronic March 4, 2009. China WEEE will enter into and electrical products which will be formulated and adjusted from time to force on January 1, 2011. time under the leadership of the Ministry of Environmental Protection and the Ministry of Industry and Information Technology subject to approval by the State Council.

- Detailed guidelines to assist the producers and consumers in understanding • Effective form August, 2004. their duty to handle E-waste in environmentally sound manner. And making it Many countries have implemented incumbent on manufacturers and distributors in EU member states to take Waste Electrical and Electronic back their products from consumers and recycle them. Directive categorises Equipment (WEEE) Directives. WEEE in to 10 categories.

- Complements to the scope of WEEE directive (except for medical devices and Effective from July 1, 2006. monitoring and control instruments). Also covers electric light bulbs and luminaries in households. It restricts/abandon the use of certain hazardous substances like lead, mercury, cadmium, chromium (VI), polybrominated biphenyls (PBBs) and polybrominated diphenyl ethers (PBDEs) in EEE and promotes the alternative substances to be use. And also provides tolerance levels in \% by weight in homogenous materials for these substances in case of its non-avoidance.

- Provides guidance for identification of various sources of waste electrical and • Approved by Ministry of Environment electronic equipments and prescribed procedures for handling E-waste in an and Forests (MoEF) on March 12, 2008 environmentally sound manner.

- To enable the recovery and/or reuse of useful material from Waste Electrical • Draft rules issued on May 14, 2010 by and Electronic Equipment (WEEE), thereby reducing the hazardous wastes MoEF for inviting suggestion and destined for disposal and to ensure the environmentally sound management objections, if any, before its enforcement. of all types of waste electrical and electronic equipment.

-E-waste is referred as "Used Consumer Electric Goods Discarded by Consumers" covering TVs, refrigerator, washing machines and air conditioners.

- Enacted in June 1998 and was enforced

-E-waste is covered under "used goods (means any articles that are collected, • Promulgated in April 26, 1991 amended used or unused, or is disposed of, excluding radioactive materials or those contaminated thereby) and by-products (means any articles obtained secondarily in the process of manufacturing, processing, repair or sale of the product; in process of supply of energy; or in the process of construction pertaining to architecture and civil engineering excluding radioactive materials or those contaminated thereby)." It covers items like PCs and other electronic items.

E-waste laws in Japan, makes manufactures and importers to take back waste electronics for recycling and waste management. And it also ensures the separation of E-waste stream from the municipal solid waste.

- Under this law consumer electronics and white goods (major household appliances like stoves and refrigerator, typically furnished with white enamels) was classified as special waste, which need to be handled separately from other residential and commercial wastes, however no specific and clear guidelines was given for its handling. in 1993, 1999 and 2000 and was in enforce in July 1, 2006. 
Table 1 (continued)

\begin{tabular}{ll}
\hline Laws and regulations & Major content \\
\hline $\begin{array}{l}\text { United Kingdom } \\
\text { - Waste Electrical and Electronic Equipment, } \\
\text { as derived from the WEEE directive, } \\
\text { an EU directive. }\end{array}$ & $\begin{array}{l}\text { - The legislation has put the responsibility of the reporting, financing and } \\
\text { treatment compliance obligations on the operators (private sector) of the } \\
\text { producer compliance schemes, instead on each individual producer. Also the } \\
\text { operator is responsible, for registering its members with the appropriate } \\
\text { national regulator and for providing the details of equipment produced by the } \\
\text { members. The producers, pre-processors and exporters need to get registered } \\
\text { with the producer compliance scheme by paying the fee, which can be used as } \\
\text { an operational cost for running the scheme. The national regulator fixes the } \\
\text { household WEEE quota for each producer compliance scheme. And the } \\
\text { operator has to ensure that the WEEE allotted must be treated using best } \\
\text { available treatment, recovery and recycling techniques. }\end{array}$
\end{tabular}

Status/date

United States of America ${ }^{8}$

US EPA has initiated a green National Electronics Action Plan (NEAP) to address environmental concerns of electronics. The scope of NEAP is restricted to computers, televisions and cell phones. However US have not ratified the Basel convention. Also there is no federal legislation in place prohibiting or regulating E-waste generation, disposal and export. Since 2003, many states in US have taken efforts for collection and recycling of E-waste from residential and commercial consumers in environmental friendly manner. Fifteen states have introduced the producer responsibility bills.

- The state of California has introduced a law for collecting the Advance Recycling Fee (ARF) from the consumer at the time of purchase of new

- Advance Recycling Fees (ARFs) in Stat Electronic Waste (SB 50, Sher)

- The Electronic Product Recycling Law chapter 70.95 N RCW in State of Washington. items like TVs, laptops and monitors.

-Manufacturers of computers, computer monitors, laptop, portable computers In 2006, by Washington State Legislature. and televisions have to provide free recycling services in Washington State to all their customers including households, small businesses, local governments, charities and school district.

- E-waste program in State of Maine.

- It covers monitors, TVs and laptops by households. In this system the responsibilities of collection process and its cost is shared by municipalities, while the manufactures share consolidation, transportation from consolidators to processors and processing cost.

- Requires manufacturers to develop programs to manage the collection and recycling of electronic devices. The law also prohibits the sale of any covered electronic device unless the device is labeled with a permanently affixed and readily visible brand that has been registered with the Hawaii Department of Health

- Fifteen out of the 21 state/cities of US have introduced producer responsibility Bill was passed in 2007.

- Producer Responsibility Bill in 15 States of US. bills; Connecticut, Hawaii (+ARF bills), Illinois, Massachusetts (+ ARF bills), Maryland, Minnesota, Nebraska, New Jersey (+ ARF bills), New York, Oregon, Rhode Island, South Carolina ( + ARF bills), Tennessee, Vermont and New York City. - A bill to restrict certain export of electronic waste

- The Electronic Waste Recycling

- Transcribed into UK legislation after being passed by Parliament in 2007.

September 29, 2004

- Started in January 2006.

Passed in 2008. Effective from January 1,2010

- Bill was referred to Energy and commerce committee 21/05/2009.

South Africa ${ }^{9}$

- National Waste Management Strategy

(NWMS) of South Africa and the Polokwane Declaration 43, towards reducing and managing the waste stream.

- The reduction in the generation and environmental impact of all forms of waste, Started in 1997. along with ensuring the people's health and ecological footprint, is the overall objective of the NWMS. This is based on the Integrated Pollution and Waste Management (IP\&WM) for addressing all elements in the waste management hierarchy. E-waste is on top priority for DEAT as part of the NWMS in waste stream. The Department of Environmental Affairs and Tourism (DEAT) and the Department of Water Affairs and Forestry (DWAF) initiated the NWMS, financed by Danish Cooperation for Environment and Development (DANCED) organization.

South Korea ${ }^{10}$

- The Extended Producer Responsibility (EPR) Law.

- It makes compulsory for the local distributors, manufacturers and importers of consumer goods like air conditioners, PCs and TVs to open an account with the government for depositing recycling funds in accordance with the quantity of the waste to be recycled. They must also achieve the official recycling targets set by the concern authority, either by outsourcing to the professional recycling companies, industry cooperatives or to set their own waste recycling facilities. If the target is not achieved they will be financially penalised. If the customer purchases a similar product, retailers and suppliers are also required to collect and transport used equipment for free.

Switzerland ${ }^{11}$

- The legislation on the Return, the Taking Back and the Disposal of Electrical and Electronic Appliances (ORDEA).

- It covers collection, transportation, recycling/treatment and disposal of E- Introduced in July, 1998. waste.

Taiwan $^{12}$

- The Waste Disposal Act Amendments (AWDA).

- It ensures a financial responsibility of recycling waste on manufacturers and • Enforced in Taiwan in March 1998 importers by levying recycling fee on them, like the Korean system. Funds are collected and transferred to the recycling facilities by an organization "Recycling Management Fund" established for this purpose. The E-waste includes TV sets, refrigerators, washing machines, air conditioners, PCs and others. Recycling fees ranges between US $\$ 8$ and US $\$ 21$ (US $\$ 1=$ TWD 32). 


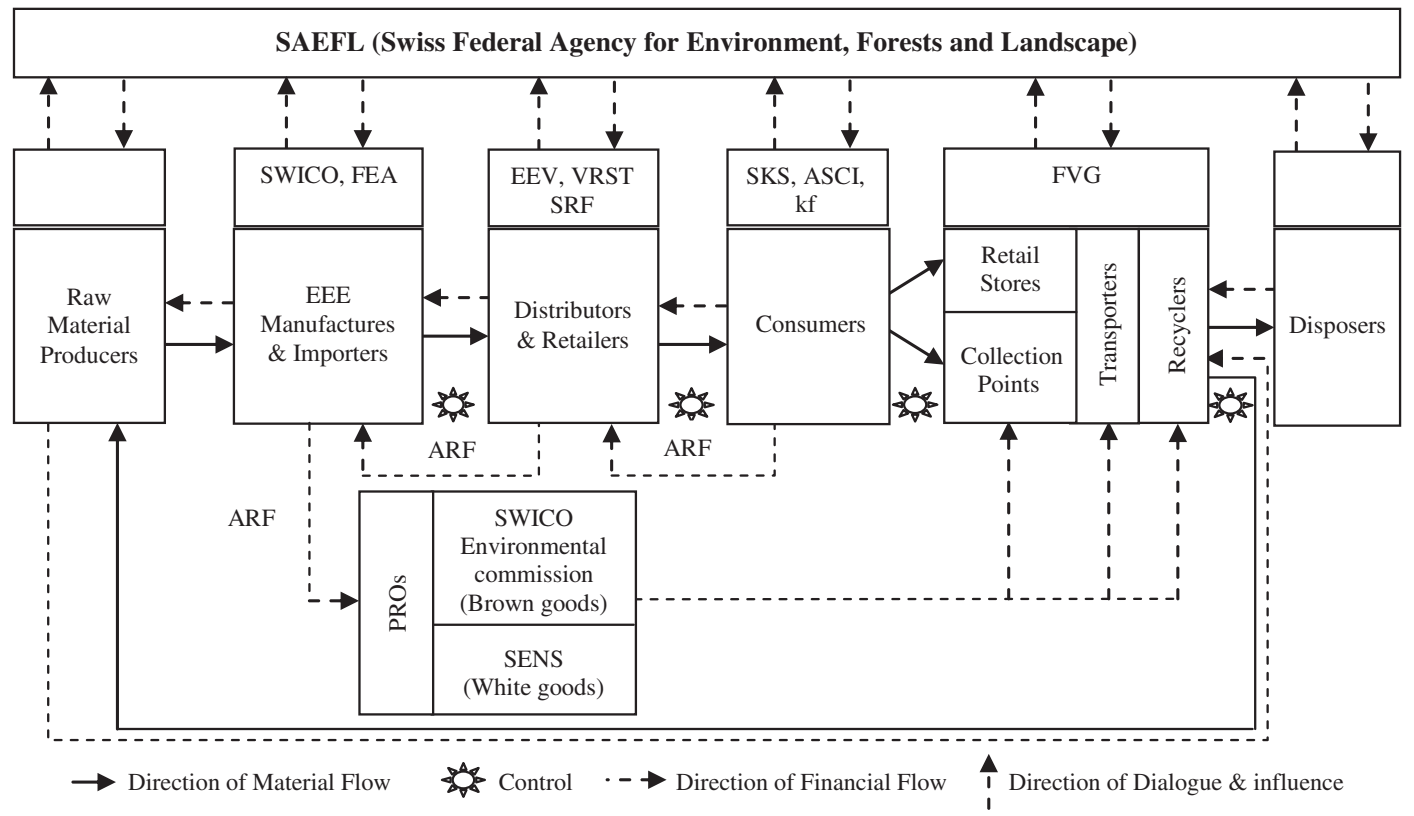

Fig. 2. Material and financial flows in Swiss E-waste management system.

consumers are willing to pay small amount of money as ARF at the time of purchasing the new product rather than paying for the useless and worthless product which they are going to disposed of (Khetriwal et al., 2009). The recycling fee in Switzerland is based on the sales of EEE and the costs for the collection and recycling of the E-waste generated. The consumers willing to dispose of their E-waste are free to deposit the old or obsolete appliances, irrespective of the brand or year of manufacture, free of charge to any retail shop or 500 official collection points (in 2003) around Switzerland of SWICO and S.EN.S, thereby making it easier for consumers to dispose of their E-waste at appropriate locations (Khetriwal et al., 2009).

The smooth functioning of the system is ensured by multiple levels of independent controls on material and financial flows at every stage, which checks on free riding and pilferage as well as ensures that the recyclers maintain quality and environmental standards (Khetriwal et al., 2005). And also prevent the illegal import and export of E-waste to and from Switzerland. Switzerland does not permit the export of E-waste to non-OECD countries as been a signatory to the Basel Convention Ban Amendment.

Implementation of ARF system poses several challenges. The recycling of discarded old appliances may require more money than that has been collected in the form of ARF on new appliances. A cross subsidisation of products among different categories - a situation where, for example, TV buyers pay for the recycling of refrigerator. The Swiss systems has integrated these limitations very effectively in the sense that, the Swiss ARF work is an intergenerational contract between the purchase of the appliances in past and future, similar to a pension system. The risk associated with setting of such an intergenerational fee is the requirement of accurate estimation of quantity of waste generation and new products sales. Further, the system has set a visible recycling fee that is easy to understand, transparent to administer and does not cross-subsidise product categories or cause consumer resentment. Both SWICO and SENS show two feasible options of setting such a recycling fee. SWICO Environmental Commission, comprising of producers from the various industry verticals, participates in setting and revising the recycling fee annually. Product price index is used by the SWICO for calculating the recycling fee. The recycling fee ranges from zero to $\mathrm{CHF}$ 1500, for products cost below CHF 50 and above CHF 600,001 respectively, in 2005 . The fee structure is slightly different for the consumer electronics as per the product category. While SENS has classified the products in to six distinct categories, depending upon the type and size of the product, for which recycling fee ranges from CHF 1 to CHF 40(in 2004). It has been made mandatory by law (Ordinance on the Publication of Prices, 1978) for all the retailers to inform customers about the final price of the product including the ARF. The SENS project team, with representatives of producers, retailers and recyclers meets twice a year to review the operations and for setting the recycling fees (Khetriwal et al., 2005). Another key feature of the system is its comprehensive scope and nationwide acceptance (Khetriwal et al., 2009).

Also APR system may lead to PRO and recycler monopolies, which may disadvantage consumers in the long run. However, problem of monopolies have always been associated with the waste management

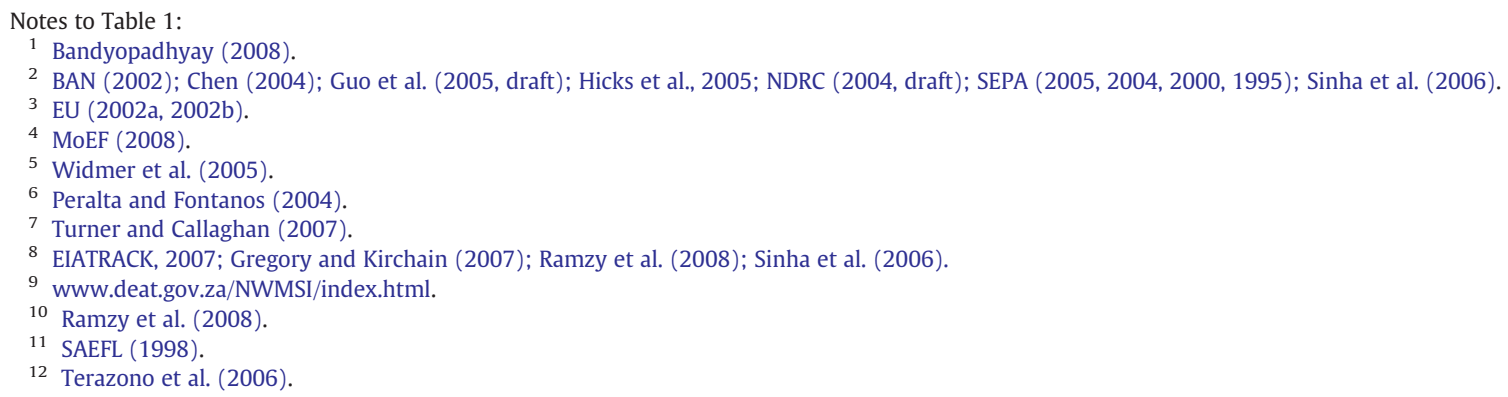


and recycling fields in particular (Lindhqvist, 2000). Transparent contract procedures and regular inspection by regulatory authorities of the PROs and recyclers overcomes the concerns of monopolies in Swiss system. In terms of above the Swiss system is by far a well organised system for E-waste management.

\section{Indian E-waste scenario}

\subsection{Current E-waste management in India}

\subsubsection{Increasing quantum of E-waste}

Since 1990, the first phase of economic liberalisation, the problems associated with E-waste in India have started manifesting. The preliminary estimates carried out by National WEEE task force in 2005 suggest that total WEEE generation in India is approximately 146,000 tonnes per year. The top states in order of highest contribution to WEEE include Maharashtra, Andhra Pradesh, Tamil Nadu, Uttar Pradesh, West Bengal, Delhi, Karnataka, Gujarat, Madhya Pradesh and Punjab. The ranked list of cities as WEEE generators are Mumbai, Delhi, Bangalore, Chennai, Kolkata, Ahmadabad, Hyderabad, Pune, Surat and Nagpur in the order (IRGSSA, 2005).

A GTZ-MAIT Study in 2007, had put the estimate to 330,000 tonnes (GTZ-MAIT, 2007) and in 2009 various sources including (Heimbuch, 2009) has put the figures to 420,000 tonnes. While the current (of 2010) E-waste generation equipment wise as per the estimates of UNEP report 2010 , is over 100,000 tonnes from refrigerators, 275,000 tonnes from TVs, 56,300 tonnes from personal computers, 4700 tonnes from printers and 1700 tonnes from mobile phones. The data only includes equipment generated nationally but does not include waste imports (both legal and illegal) which are substantial in emerging economies like India and China (UNEP report, 2010). Whereas a report by Toxics Link (2004) said that at recycling units in New Delhi (India) itself, $70 \%$ of the total electronic waste collected was actually exported or dumped by developed countries (Toxic Link, 2004).While the GTZ-MAIT Study in 2007 estimates that around 50,000 tonnes of WEEE were imported to India every single year (GTZMAIT, 2007). There is a urgent need to decide a strategy for E-waste problem in developing country like India, as the UNEP 2010 report predicts that by 2020, E-waste from old computers in India will jumped by $500 \%$; from discarded mobile phones will be about 18 times high; from televisions will be 1.5 to 2 times higher; from discarded refrigerators will double or triple; than its respective 2007 levels.

\subsubsection{Complex E-waste trade cycle}

Unlike Switzerland, the India's E-waste management system is not formally developed. Moreover it is very ill defined and unorganised. The Fig. 3 presents the schematic overview of physical and financial flows of EEE in India.

Based on the study and analysis, of the Indian E-waste scenario, the life cycle of the EEE in India can broadly be divided in to three levels.

\subsubsection{Level I - EEE generation}

The first level marks the actual entry of the new electrical and electronic equipments, raw materials, components, assemblies and sub-assemblies in India either in the form of production/manufacturing, by the producers and manufacturers who are located in India, or in the form of its import from the foreign countries by the importers. As distributors, retailers, raw material suppliers are not the real user of these EEE items and raw materials, they are considered as the actors of the EEE generation only rather than of the WEEE generations. Up to this level the sector is well organized in India. Although for few EEE items especially in the case of the personal computers, 'Assemblers' are also involved in the EEE generation, who purchases the local made or branded components, assemblies and sub-assemblies from the raw materials manufactures and suppliers, assembled it and directly sells it to the consumers, in the grey market, at much cheaper rate compared with the branded PCs, which makes the quantification of Ewaste in India more difficult. High level of overall taxation like Value Added Tax (VAT); Excise Duty; Customs Duty; Service Tax, License fee (on software) etc. on the purchase of the new branded PC makes the branded PC costlier compared with the assemble one. This may be one of the reasons for thriving grey market for electronic and electrical items in India. And the existence of such non-identifiable producers is one of the major challenges to the prospect of any EPR programmes (Manomaivibool, 2009).

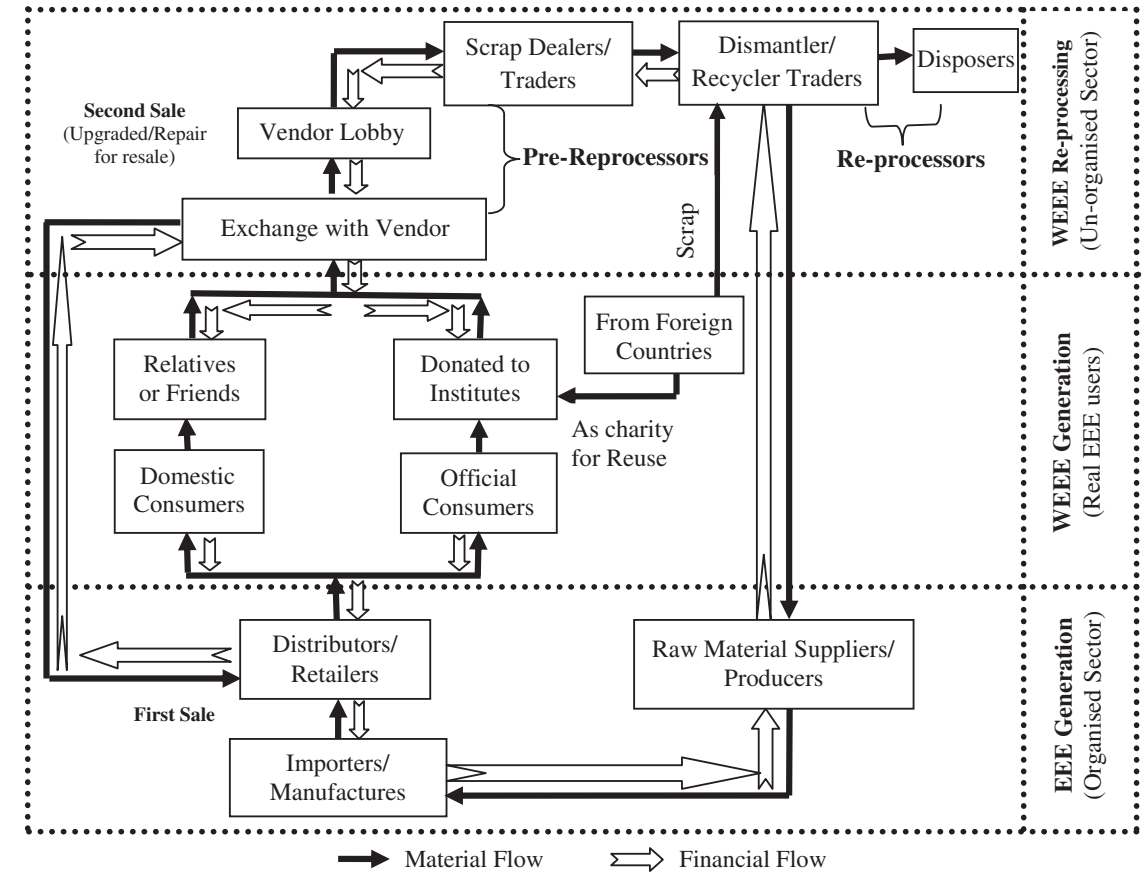

Fig. 3. Existing E-waste trade system flows in India. 


\subsubsection{Level II - WEEE generation}

This level is mark by the WEEE or E-waste generation. The domestic as well as official consumers are the real users of EEE, who purchases the generated new EEE from the actors of first level, in order to serve their present need. Often in case of the personal computers, TVs, etc. the consumers discard their old items for the sake of latest version, features and options to meet their present need. In India the EEE may find more than one user, as the first user may resale or give the used EEE to their relative or friend for further use in case of domestic consumer. Practices may also be found of donating the used EEE by the official consumers to the economically week social institutes like charitable schools; hostels; orphanage; hospitals, village societies, etc. It was also been reported that large amount of WEEE enters India from the foreign countries without paying any duty in the name of charity (Karla, 2004; Kimberley, 2007).

\subsubsection{Level III - WEEE re-processing}

This level can be further divided as pre-reprocessing stage and reprocessing stage, the actors involved are mostly unorganised. In pre-reprocessing stages collection of the E-waste is mostly done by the un-organized sector of scrap dealers/traders, called as "Kabadiwala" in local language, who purchases E-waste along with the other recyclable waste or scrap like old news papers, books, cardboards, plastics, ferrous-tin material items, glass bottles, etc., from the consumer, and sell it through small traders to the wholesaler/bigger trader who segregates and sort out different types of waste material components, and ultimately sells it to the recycler/dismantler and disposers for reprocessing. Thus in India, E-waste is one of the part of the total recyclable waste or scrap, which are been purchase by the Kabadiwala from various consumers like individual houses, offices, institutions, government, commercial and industrial establishments, etc. In many government and private establishments these scrap or reusable/ recyclable items are auctioned through advertisements in the news papers. The recycler/dismantler dismantles the E-waste and the readily reusable/recyclable materials like plastic, glass, cable-wires, components, etc. are resale back to raw material supplier for reuse. While the remaining E-waste is reprocess to recover the valuable materials like copper, gold, silver, aluminium, etc. from it and then dispose-off the residual waste either in an incinerator or in a landfill, open dumping of the residual or un-recoverable E-waste, along with acids used in extraction, on the open land and water bodies was also reported (MPCB, 2007). Thus, the entire system is based on a network existing amongst the collectors, traders and recyclers, each adding value, and creating jobs, at every point of the chain. And thus this chain is also the network of activities involving reuse, recycling and final disposal of WEEE and its associated components, sub-assemblies and materials. Many times the EEE finds its way into the second sale market (with or without up-gradation). As sales and trade-in of used electronics is invisible to the statistics collection system which makes quantification of E-waste very difficult in India.

\subsection{Impacts of the informal recycling of E-waste in India}

\subsubsection{Economical and social}

Many of the EEE, mainly computers, television, telecommunication equipments etc. are very important for the social and economical development of any community and country. EEE plays key role in running and development of the modern business, administrative and in education field. But due to the social and economic disparity in the developing countries like India compared with their counter parts in developed countries many people lacks the use of the new EEE. The considerable price difference between the new and used EEE makes the consumer to go for the purchase of the second hand EEE in developing countries like India, which may be one of the factor for the growth of E-waste recycling market in India. E-waste recycling is a market-driven and growing industry in India (Haque et al., 2000). The low initial investment required for starting a collection, dismantling, sorting, or a recovery activity makes the business very attractive for small entrepreneurs. Rather than creating environmental or social awareness the financial profit is the main incentive for the facility owners in India. Also, as most of the labourer working in this sector is poor literate and un-educated, they are little or completely not aware about the harmful effects of E-waste recycling on their health and environment. As collection, dismantling, sorting-segregation and recovery of E-waste are mostly done manually, in India this business has significant employment potential (Baud et al., 2001) in several cities. An Empa's pilot study for Delhi estimates the number of unskilled workers involved in recycling and recovering operations, to be at least 10,000 people in Delhi itself (Empa, 2004). In the developing countries like India recovering reusable machines, components and materials from discarded WEEE is a source of income for poor people. Thus, the E-waste recycling sector opens the job opportunities and source of income, which also needs to be understood and addressed while framing the E-waste management system for India.

\subsubsection{Occupational and environmental}

A variety of tools are involved in the dismantling process for removing the components and recovery of reusable or valuable components and materials. Mainly the mechanical/physical recycling processes practised involve screening, shape separation, magnetic separation, electric conductivity-based separation, density based separation, and such other techniques depending upon the quantity, type, size and shape of the material and component in E-waste (MPCB, 2007). Although efforts have been made to document E-waste recycling activities in big cities like Bangaluru, Chennai, Mumbai, New Delhi, and Pune by various environmental organizations, pollution control boards, municipalities, etc. in order to highlight the serious implications of informal recycling to the environment as well as human health, still lot of ground to be covered in this matter.

The biggest drawback of the current E-waste system in India is the uncontrolled emission of pollutants that are going into the air, water and soil, which are neither quantified nor monitored. The health hazards from fumes, ashes and harmful chemicals affect not only the workers who come into contact with the E-waste, but also others who are exposed to the E-waste environment. The total E-waste management system is labour intensive and most of the recycling and recovery operations are carried out using outdated technologies and processes, that may lead to release of uncontrolled emission of pollutants (EU,2000), (SVTC, 2006). The Table 2 gives the associated occupational safety and environmental hazards due to E-waste. Based on the study and analysis of the present E-waste system of India, the drivers are pointed out, as shown in Table 3, that can positively (termed 'facilitators') or negatively (termed 'constraints') alter an existing E-waste management system in India. Also the scientific, engineering and organisational challenges (Wath et al., 2010), which need to be taken care are indicated in Table 4 .

\subsection{Legislation in India related to E-waste}

Ministry of Environment and Forests (MoEF) is the national authority in India and is responsible for legislations regarding waste management and environmental protection. So far, MoEF has issued letter no. 23-23/2007-HSDM dated March 12, 2008, the guidelines for environmentally sound management of E-waste with an objective to provide guidance for identification of various sources of waste electrical and electronic equipments and prescribed procedures for handling E-waste in an environmentally sound manner (MoEF, 2008). There is no corresponding law or regulation specifically addressing the E-waste problem, in view of most of the hazardous and nonhazardous materials found in the E-waste are covered under the purview of "The Hazardous and Waste Management Rules, 2008" and "Municipal Solid Waste Management Rules, 2004." The roles of the 
Table 2

Occupational safety and environmental hazards due to E-waste.

Puckett et al., 2002 (http://ban.org/E-waste/technotrashfinalcomp.pdf (Feb. 2002).

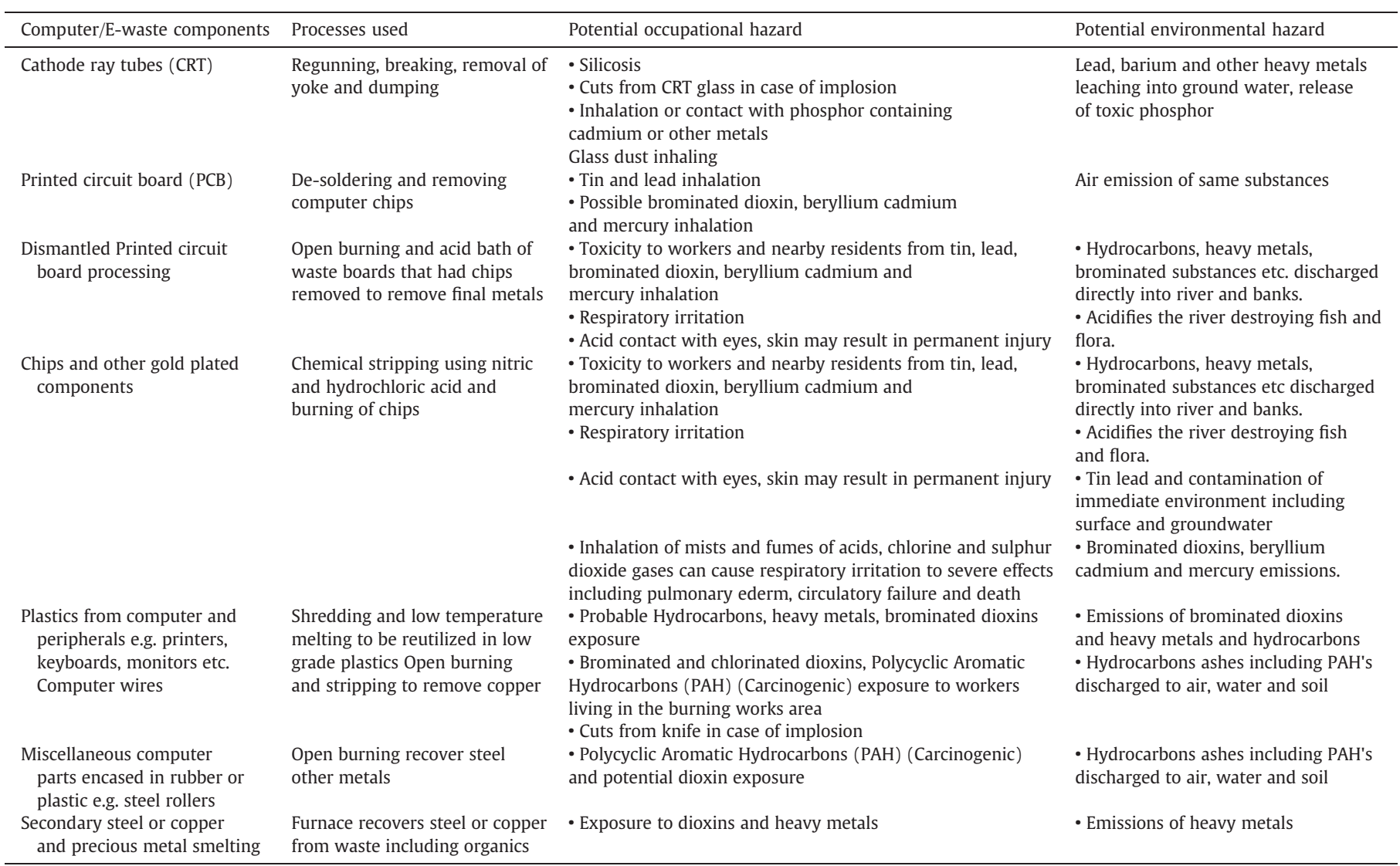

concerned regulatory and monitoring agencies as well of other stakeholders (Actors) are not well defined specific to the E-waste problem. Also, in India, administrative delays in law enforcement is one of the barrier (UNEP, 2009). Unlike in Japan, Philippines, U.S., etc. (Section 2) where the EEE items are classified as special waste by law, which need to be handled separately from other residential and commercial wastes, in India E-waste is being treated as the municipal waste and no special attention is given to the activities related to its collection, handling, dismantling and recycling by the local government. A Toxic Link report of February 2003, highlighted the need for legislation to ban the import of E-waste as well as ensure environmentally sound disposal of the domestically generated Ewaste (Toxic Link, 2003). With the rapid increase in the E-waste generation in India there is a need for specific law pertaining to Ewaste (Srinivasan and Bhambri, 2009) which clearly defines the E- waste (MoEF, 2008). However, on May 14, 2010, MoEF has issued a draft E-waste (Management and Handling) Rules, 2010. The draft rules is based on the Extended Producer Responsibility (EPR) approach, meanwhile many aspects and issues such as social and economical implication, positive and negative drivers(as discussed in Section 4.3) of the current E-waste Indian scenario, which need to be taken care are not addressed in the draft E-waste rules, 2010. These issues along with other approaches and systems practiced worldwide are discus in Section 5 to best suit the Indian scenario.

\section{Discussion of various approaches, systems and practices in Indian context}

The E-waste management strategy or policies can be design on measurable trends or evidences with an identified drivers as an

Table 3

The characteristics of E-waste system in India and its implications.

\begin{tabular}{|c|c|c|}
\hline Activities/drivers & Facilitators & Constraints \\
\hline Sale of WEEE by consumer against value. & $\begin{array}{l}\text { Incentive/motivating factor for consumer for } \\
\text { disposing of the WEEE. }\end{array}$ & Un-valuable EEE is dumped along with municipal solid waste. \\
\hline Second sale of EEE. & Increase in the working lives of the EEE. & May lead to overuse of EEE up to the level of accidents. \\
\hline Reuse/recycling of scrap e.g. plastic, wires, glasses, etc. & $\begin{array}{l}\text { Increase in the lifetime of the EEE/components. } \\
\text { Increases resource utilization efficiency. }\end{array}$ & $\begin{array}{l}\text { Poor quality/impure material may be reuse/recycled. Will } \\
\text { necessarily become waste sooner or later. }\end{array}$ \\
\hline Labour intensive system & $\begin{array}{l}\text { Employment of local people/Local economic } \\
\text { growth. }\end{array}$ & Health hazard, time consuming \\
\hline Involvement of non-technical/unskilled peoples. & $\begin{array}{l}\text { Cost saving/profitable businesses may be } \\
\text { generated }\end{array}$ & Health hazard, lack of process efficiency/affectivity. \\
\hline $\begin{array}{l}\text { Manual operations/dismantling/recycling/non-scientific } \\
\text { treatment process, outdated technologies. }\end{array}$ & $\begin{array}{l}\text { Cost saving/profitable businesses may be } \\
\text { generated. }\end{array}$ & Health hazard, environmental pollution, time consuming. \\
\hline Totally market-driven, unorganised and informal sector. & $\begin{array}{l}\text { Low initial investment, entry and exit in the WEEE } \\
\text { business are easy. }\end{array}$ & $\begin{array}{l}\text { Very less or no control of regulatory bodies, unfair trading } \\
\text { practices, quantification of WEEE is very difficult. }\end{array}$ \\
\hline
\end{tabular}


Table 4

Challenges for E-waste system in India.

\begin{tabular}{|c|c|}
\hline Scientific challenges & Engineering challenges \\
\hline - Eco-friendly recovery solutions & - Scientific collection, transport, handling, \\
\hline$\circ$ Base metals & - Integrated/distributed processing \\
\hline - Value addition to recyclables for reuse & facilities \\
\hline$\circ$ Plastics & ○ Unorganized to organized \\
\hline - Glass and other recyclables & - Involvement of SMEs and NGOs \\
\hline $\begin{array}{l}\text { - Disposal of process waste and residues } \\
\circ \text { Size reduction }\end{array}$ & $\begin{array}{l}\text { - Feasible techno-economical solutions } \\
\circ \text { Processing }\end{array}$ \\
\hline ○ Toxic reduction & $\begin{array}{l}\text { - Recycling } \\
\circ \text { Recovery }\end{array}$ \\
\hline \multicolumn{2}{|l|}{ Organizational challenges } \\
\hline \multicolumn{2}{|c|}{ - Appropriate definition for E-waste in Indian context } \\
\hline \multicolumn{2}{|c|}{ - Inventorization of E-waste generation, import and its characterization } \\
\hline \multicolumn{2}{|c|}{ - Organization and structuring E-waste management system } \\
\hline \multicolumn{2}{|c|}{ - Training and awareness on SHE (safety, health and environment) } \\
\hline
\end{tabular}

starting point, rather than adopting best practices system from elsewhere, which may not address local characteristics, customs, peculiarities, social and economical culture (Agamuthu et al., 2009). Based on pro-actively driven trends/evidence/facts ideal policies can be formulated (Wilson, 2007) which ensures the practicality and realism of policies. Table 5 summarizes the various approaches, systems and practices adopted by various countries which are studied and discuss in this section in respect of its selection, applicability and feasibility in the Indian context. From the study it is found that majority of the governments have opted to make producers responsible for taking back and disposal of their EEE due to the financially self sustaining mode of system.

\subsection{Extended Producer Responsibility (EPR)}

Extended Producer Responsibility (EPR) is defined as an environmental protection strategy that makes the manufacturer of the product responsible for the entire life cycle of the product and especially for the take back, recycling and final disposal of the product (Lindhqvist, 2000). Thus, the producer's responsibility for a product is extended to the post consumer stage of a product's life cycle (OECD, 2001). It also includes 'Producer Responsibility Model (Mandatory take back)' in which it is mandatory for the retailers and manufacturers to take back their own products and a percentage of "orphaned" electronic products for recycling. This option provides incentives for manufacturers to improve their technologies, because these firms must cover the cost of recycling (Columbia University, 2006). As discussed in Section 4, in India there are existence of many nonidentifiable small and medium scale industries, which are producing the low cost EEE and selling their products in the white as well as grey market. Due to which this option may not be feasible for such producers/manufacturers as most of them lack the infrastructural and economical capabilities for adopting this system. Also model warrants a system for monitoring how companies recycle their products, considering the total numbers of identifiable and non-identifiable manufactures/producers/importers in the country, it may be very difficult to monitor the recycling system of each and every industry.

\subsection{Advance Recycling Fee (ARF)}

Consumers pay tax when they purchase their electronic device that is meant to cover the future cost of recycling (Columbia University, 2006). Unlike Switzerland, where consumers pay for the recycling of their WEEE, but there is no end-of-life incentive to recycle E-waste, in India there exists a effective and well developed door-todoor collection of WEEE by Kabadiwala, as discussed in Section 4, moreover Indian consumers are willing to give their WEEE to Kabadiwala and getting value against their WEEE. These will substantially reduce the infrastructural and working cost require for collection and transportation of WEEE to recyclers/disposer for developing the E-waste management system in India. Considering these facts the visible ARF (explicitly mentioned on the price of the product as an addition component giving the value of the recycling fee charged as per the Swiss system) should be set and revise time to time, based on the categorization of the electronic and electrical goods, in consultation with the technical experts and the various associations related to electronic industry like Consumer Electronics and TV Manufacturers' Association (CETMA), Electronic Industries Association of India (ELCINA) Manufacturers' Association for Information Technology (MAIT), Telecom Equipment Manufacturers Association of India (TEMA). The burden of the fee to be equally share by consumer as well as by manufacturer/producer/importer and should be worked out based on the principal of the Indian Government Provident Fund Scheme ${ }^{1}$.

\subsection{Tax credits}

Tax credits are distributed to consumers who bring their electronic waste to be recycled and to agencies that collects electronic waste for recycling. This option may encourage the development of an electronic waste recycling market (Columbia University, 2006). In the Indian scenario, the consumers are willing to return back their E-waste to the collectors in return of money, which serves as a motivating factor for the consumers as discussed in Section 4. Though, the tax credit to consumer may be an additional administrative and financial burden on the government, the option can be considered for the producer/manufactures who adopted the concept of Eco-design i.e. adopted innovative activities for developing the cleaner electronic and electrical products which are more durable, energy efficient, avoid the use of toxic materials and which can be easily disassembled for recycling (Roy, 2000; Sherwin, 2000; Lewis and Gertsakis, 2001; Bhamra, 2004). Although China has adopted this Eco-design concept in law (see Section 2) but have not given any incentive to attract more manufacturers for its adoption. In India the option can also be considered for the E-waste recycler/ reprocessor. To enable this system, appropriate guidelines for the recycling of electronic waste, along with identification and certification process for all electronic waste recyclers and manufactures/producers are required in Indian scenario.

Some of the opportunities and limitations of adopting the ecodesign concept by the manufactures and producers are also summarise in Table 6 which need to be analysed and consider in Indian perspective for adopting tax credit option. The factors which influence a manufacturer/producer firm decision to adopt eco-design are discuss in detail by the author Gottberg et al., 2005 and Van Hemel and Cramer, 2002.

\subsection{Deposit-refund system}

Consumers pay a fee when they purchase an electronic device, which is reimbursed when they return the product to a certified recycler. This option provides end-of-life incentives for consumers to recycle their electronics. Considering the size of population of India (1.15 billion in 2010), EEE market segment and the life span of the EEE (which is very short varying from 1-10 years depending on the type of EEE), and growing trends of EEE market in India (as discussed in Section 1) an system for up-keep of records of sale/purchase of each and every EEE will not be practically feasible in Indian scenario. Moreover, if being adopted it may be an additional administrative burden on the producer, recycler as well as on government.

\footnotetext{
1 Note: Indian Government Provident Fund Scheme: As per amendment dated 22.9.1997 in the Act, both the employees and employer contribute to the fund at the rate of $12 \%$ of the basic wages, dearness allowance and retaining allowance, if any, payable to employees per month] (Source: http://www.epfindia.com/epf.htm).
} 
Table 5

Various EPR approaches.

Extended Producer Responsibility: A Guidance Manual for Governments (OECD, 2001).

\begin{tabular}{|c|c|c|}
\hline Type of EPR approach & Types of tools & Examples of EPR applied \\
\hline \multirow[t]{2}{*}{ Product take back programs } & Mandatory take back & Packaging (Germany) \\
\hline & Voluntary or negotiated take back programs & Packaging (Netherlands, Norway) \\
\hline \multirow[t]{4}{*}{ Regulatory approaches } & Minimum product standards & EEE, batteries \\
\hline & Prohibitions of certain hazardous materials or products. & Cadmium in batteries (Sweden) \\
\hline & Disposal bans & EEE in landfills (Switzerland) \\
\hline & Mandated recycling & Packaging (Germany, Sweden, Austria) \\
\hline \multirow[t]{3}{*}{ Voluntary industry practices } & Voluntary codes of practice & Transport packaging (Denmark) \\
\hline & Public/private servicizing partnerships & Photocopiers, vehicles \\
\hline & Leasing, "servicizing," labelling & \\
\hline \multirow[t]{3}{*}{ Economic instruments } & Deposit-refund schemes & Beverage packaging (Korea, Canada) \\
\hline & Advance recycling fees & EEE (Switzerland, Sweden) \\
\hline & Fees on disposal, material taxes/subsidies & EEE (Japan) \\
\hline Some other approaches & \multicolumn{2}{|c|}{ Tax credits, advance recovery fee, producer responsibility model, deposit refund system } \\
\hline
\end{tabular}

\section{Proposed roadmap for E-waste management system in India}

For developing an sustainable E-waste management system in India, it is important to take in to consideration the existing WEEE trading practices, social-cultural-economical background and practices, present laws and legislation, present monitoring and regulating bodies and agencies, etc. as discussed in detail in Section 4. Based on the discussion and analysis in Sections 2, 3, 4, and 5 some specific recommendations are made for consideration by the appropriate authority. And the essential elements required for the development of scientific and sustainable E-waste management in India are proposed here.

\subsection{Proper approach of the E-waste management system}

The propose Indian E-waste management system should be based on the EPR approach (as discussed in Section 5.1), which shall use a control and command approach for its enforcement and is marketoriented regulatory instrument, with an objective of achieving; i) reduction in WEEE volumes generated; ii) reduction in WEEE disposed; iii) reduction in hazardous constituents in the WEEE stream; iv) decrease in virgin material use; v) lowering of pollution in the production stage; and vi) increase design for environment. It is proposed to implement an "Extended Producer Responsibility (EPR)" based on the "South Korean-EPR Law" (Section 2), obliging producers to cover the costs of collection, recycling and disposal. Producers responsibilities will includes using designs beneficial to recycling, choosing non-toxic, non-hazardous, and recyclable materials, and providing information to aid recycling.

\subsection{Financial sustainability of system}

The visible ARF in line with the Indian Government Provident Fund Scheme is proposed for achieving the financial sustainability of the system (as discussed in Section 5.2). The tax credit benefit should be extended for the producer/manufactures/traders who are improving products for easier recycling or reclamation and restricting/stopping the use of hazardous and toxic materials in EEE. Tax credit benefit option can also be considered for the E-waste recycler/processor. The tax credit will encourage the manufacturer and producer for the use of non-hazardous and non-toxic materials in the EEE (as discussed in Section 5.3).Traders and Manufacturers Association (like CETMA, ELCINA, MAIT, TEMA, etc.) to make the future projections on volumes of WEEE and also the per capita WEEE generation; NGOs (Toxic Links, etc.) for environmental and occupational concerns of the system; informal collectors/recyclers for WEEE collections from consumers; formal recyclers (E-Parisara, Bangaluru, Trishyiraya Recycling Indian Pvt. Ltd., Chennai, Eco Recycling Limited, Mumbai, etc.) for their technical expertise and experience in setting the ARF and establishment of recycling/treatment facilities.

\subsection{Clear and defined role of the government}

Role of the Indian Government in formulating the policy, laws and legislation, formation of task force for E-waste management system will be of great importance, and so as of municipalities, Pollution Control Boards (CPCB, SPCB) for regulation and implementation. In India, there exists several environmental legislations which are of importance and useful for addressing the E-waste problems. The

Table 6

Eco-design and waste minimisation: Opportunities and limitations.

Adapted from Lewis and Gertsakis (2001), Van Hemel (1998) and Persson (2001).

\begin{tabular}{|c|c|c|}
\hline Opportunity & Achieved by & Potential disadvantage/limitations \\
\hline Reduced product size/mass & $\begin{array}{l}\text { - Using less bulky, less heavy materials } \\
\text { - Reduced product dimensions } \\
\text { - Making products foldable for storage and transport }\end{array}$ & $\begin{array}{l}\text { - Less bulky materials may be more complex and thus unfavourable for recycling } \\
\text { - Increased efficiency in material use may result in cost and price cuts that } \\
\text { encourage increased production and consumption, with limited net gain }\end{array}$ \\
\hline Extended product life & $\begin{array}{l}\text { - Using durable materials } \\
\text { - Facilitating repair through easy } \\
\text { - Dismantling and replacement of components } \\
\text { - Avoiding highly fashion-sensitive styles }\end{array}$ & $\begin{array}{l}\text { - Products become outdated in design and performance } \\
\text { - New shorter life products may have lower environmental impacts in the } \\
\text { use phase that off-set the environmental gains of a long life } \\
\text { - Obsolete products in fashion driven markets }\end{array}$ \\
\hline Improved recycling potential & $\begin{array}{l}\text { - Facilitating disassembly } \\
\text { - Reducing number of components } \\
\text { - Reducing complexity of materials }\end{array}$ & $\begin{array}{l}\text { - Some complex materials have less mass, saving energy during the use phase, } \\
\text { or are more durable than easy-to-recover materials } \\
\text { - Easily recyclable materials may have substantial environmental impacts } \\
\text { during other life cycle stages, e.g., virgin aluminium }\end{array}$ \\
\hline Improved performance in use & $\begin{array}{l}\text { - Reduced mass } \\
\text { - Use of energy saving devices } \\
\text { - Incorporating automatic controls } \\
\text { - Extended maintenance intervals }\end{array}$ & $\begin{array}{l}\text { - Increased complexity } \\
\text { - Increased risk of failure } \\
\text { - Compatibility with existing infrastructure and systems }\end{array}$ \\
\hline
\end{tabular}


Table 7

Existing legislation in India with impact on E-waste management.

\begin{tabular}{|c|c|c|}
\hline Law or regulation & Major content & Status/date \\
\hline Environment (protection) Act 1986 (amendment 1991). ${ }^{1}$ & $\begin{array}{l}\text { An umbrella legislation that empowers the central government to take } \\
\text { measures to protect and improve environmental quality, control and reduce } \\
\text { pollution from all sources. }\end{array}$ & Effective from November 19, 1986. \\
\hline $\begin{array}{l}\text { Hazardous wastes (management and handling and } \\
\text { transboundary movement) rules, } 2008 \text { (amendments } \\
\text { July 2009, September 2009). }{ }^{2}\end{array}$ & $\begin{array}{l}\text { Provides stipulations on the management, disposal and transboundary } \\
\text { movement of solid waste of hazardous nature (encompassing provisions of } \\
\text { the Basel convention) as mentioned in schedules I, II, III and IV of the rule. }\end{array}$ & Effective from September 24, 2008. \\
\hline $\begin{array}{l}\text { Municipal Solid wastes (management and handling) } \\
\text { Rules 2000. }\end{array}$ & $\begin{array}{l}\text { Provides compliance criteria to municipalities for the collection, } \\
\text { segregation, storage, transportation, processing and disposal of municipal } \\
\text { solid wastes. }\end{array}$ & Effective from September 25, 2000. \\
\hline Batteries (management and handling) rules $2001{ }^{4}$ & $\begin{array}{l}\text { Confers responsibility for the safe disposal and recycling of used lead acid } \\
\text { batteries on the manufactures/assemblers/importers. }\end{array}$ & Effective from May 16, 2001. \\
\hline $\begin{array}{l}\text { The Public Liability Insurance Act, } 1991 \\
\text { (amendment 1992). }\end{array}$ & $\begin{array}{l}\text { Covers accidents involving hazardous substances and insurance coverage } \\
\text { for these. }\end{array}$ & Effective from January23, 1991 \\
\hline National Environmental Tribunal Act, $1995 .^{6}$ & $\begin{array}{l}\text { Provide for strict liability for damage arising out of accidents caused from } \\
\text { the handling of hazardous substances. (The tribunal shall become defunct } \\
\text { and the act shall stand repealed upon the enactment of the National Green } \\
\text { Tribunal Bill } 2009 \text { currently pending in Parliament.) }\end{array}$ & Effective from June 17, 1995. \\
\hline $\begin{array}{l}\text { The Water (prevention and control of pollution) } \\
\text { Act (amendment 1988). }\end{array}$ & $\begin{array}{l}\text { Provide for the prevention and control of water pollution, and for } \\
\text { maintaining or restoring of wholesomeness of water in the country. }\end{array}$ & Effective from March 23, 1974 \\
\hline $\begin{array}{l}\text { The Water (prevention and control of pollution) } \\
\text { Cess Act } 1977 \text { (amendment 2003). }\end{array}$ & $\begin{array}{l}\text { Provide for the levy and collection of a cess on water consumed by persons } \\
\text { operating and carrying on certain types of industrial activities. This cess is } \\
\text { collected with a view to augment the resources of the Central Board and the } \\
\text { State Boards for the prevention and control of water pollution constituted } \\
\text { under the Water (Prevention and Control of Pollution) Act, } 1974 \text {. }\end{array}$ & Effective from December 7, 1977 \\
\hline $\begin{array}{l}\text { The Air (prevention and control of pollution) } \\
\text { Act } 1981 \text { (amendment 1987). } .^{8}\end{array}$ & Provide for the prevention, control and abatement of air pollution in India. & Effective from March 29, 1981 \\
\hline \multicolumn{3}{|c|}{$\begin{array}{ll}1 & \text { http://moef.nic.in/modules/rules-and-regulations/environment-protction/. } \\
2 & \text { http://www.envfor.nic.in/legis/hsm/HAZMAT_2265_eng.pdf. } \\
3 & \text { http://www.envfor.nic.in/legis/hsm/mswmhr.html. } \\
4 & \text { http://www.envfor.nic.in/legis/hsm/leadbat.html. } \\
5 & \text { http://moef.nic.in/modules/rules-and-regulations/public-liability-insurance/. } \\
6 & \text { http://moef.nic.in/modules/rules-and-regulations/national-environment-tribunal/. } \\
7 & \text { http://moef.nic.in/modules/rules-and-regulations/water-pollution/. } \\
8 & \text { http://moef.nic.in/modules/rules-and-regulations/air-pollution/. }\end{array}$} \\
\hline
\end{tabular}

Table 7 gives the existing legislation in India with impact on E-waste management. From the point of view of adopting HWM rules, the rules need strengthening of enlarging list of WEEE items. Also following specific actions need to be initiated at Government level, industry level and agency level for setting the E-waste management system for India:

- Elaborate and implement comprehensive government laws and regulations specific to the WEEE, on its collection, handling, dismantling and recycling along with eco-design and RoHS compliance focusing on rapid implementation. Some of the legislations as mentioned in Table 5 can be use for this.

- Setting of uniform National E-waste policy to design and develop a strategy for E-waste management.

- Establish standards and a certification system for recycling and disposal enterprises, to ensure safety and the environmentally sound processing of WEEE.

- Facilitate, establishment of WEEE recycling and disposal enterprises, as well as support the development of relevant technology, methods and education.

- Devise support systems including infrastructure development to bring down compliance costs.

- Track global compliance requirements on an ongoing basis and develop appropriate policy agenda and implementation programmes.

- Support design, testing, tooling and training, targeting as many SMEs as possible. This could be done jointly with the industry, training institutions, academia and other enabling agencies i.e. facilitating Public-Private-Partnership (PPP)

- Initiate research on cost structures of cleaner processes to suggest methods for bringing down compliance costs, particularly for the SMEs.

\subsection{Implementation, regulation and monitoring of the system}

Based on the discussion in previous sections, an organisation system in terms of a task force for integrated E-waste management system (Mundada et al., 2003) within the framework of MoEF, CPCB and SPCBs, as depicted in the Fig. 4 is proposed, with delineated roles and responsibilities of each of the constituent functional groups (Columbia University, 2006), viz.

a. Technical and certification group

b. Communications and information group

c. Legal and advisory group

d. Finance group

A national overall E-waste management system for India is proposed in Fig. 5, which comprises of flexible existing decentralised informal door-to-door collection mechanism by Kabadiwalas/small traders, which ensures the employment generation potential as discussed in Section 4 and also take care of the concern that the establishment of an EPR programme would lead to the collapse of recycling business in India (Manomaivibool, 2009). In view with present E-waste scenario in terms of social and economical condition, and also as the pre-reprocessing stage such as collection and trading, does not disperse any hazardous components into the environment from the WEEE; moreover, collecting and pre-processing can be handled efficiently by the informal sector and - at the same time can offer numerous job opportunities (Widmer et al., 2005) it is proposed not to make the registration mandatory for E-waste collectors/traders in the proposed E-waste management system for India. Although to promote the registration amongst recycler, the option of availing the ARF benefit may be kept open to only registered E-waste collectors/traders. On other hand the reprocessing stages 


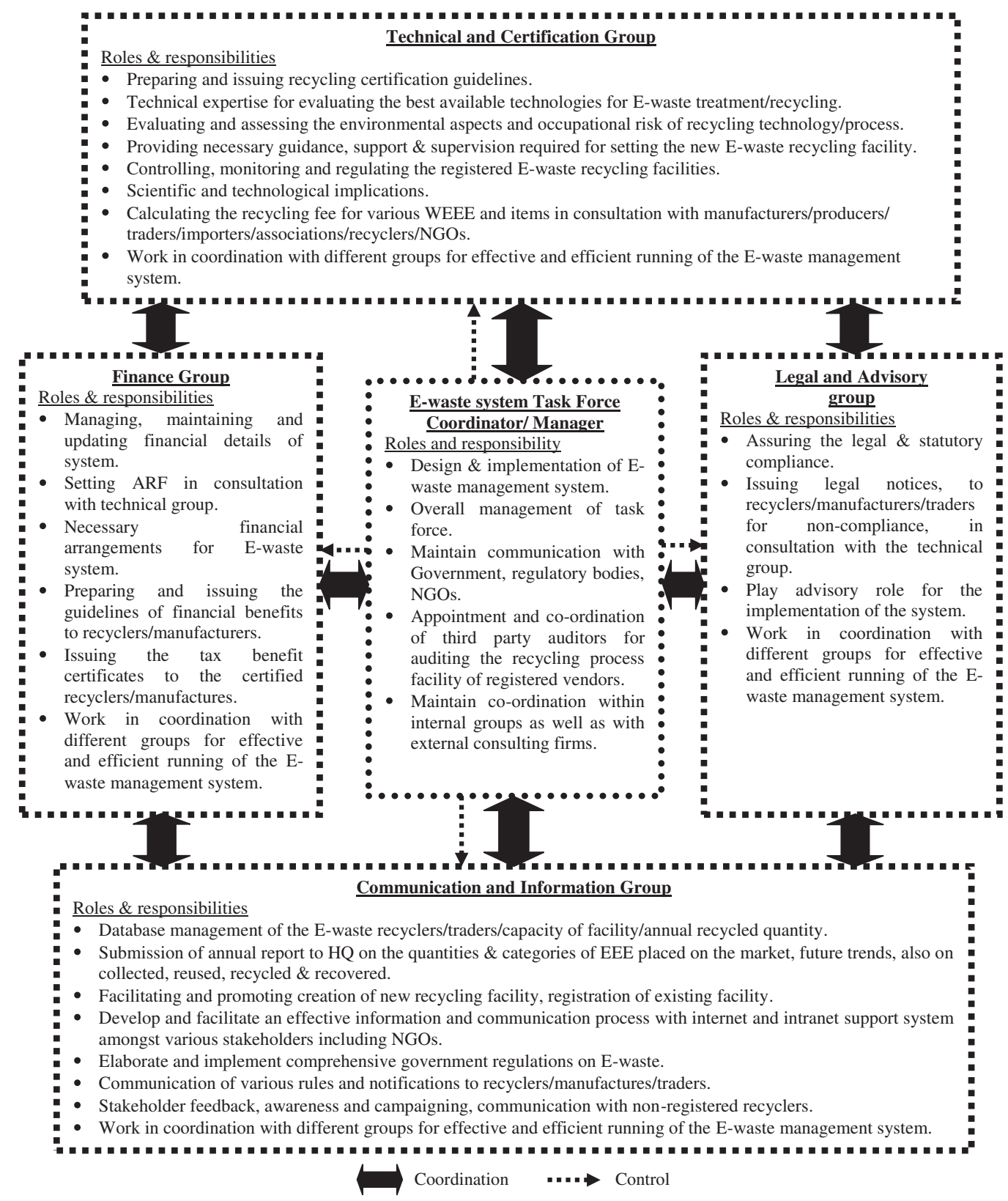

Fig. 4. Structure, role and responsibility of task force.

such as treatment/recycling involves the dispersion of hazardous materials in environment (Bandyopadhyay, 2008) and hence the registration may be made mandatory for recyclers and disposers. Also it is proposed that the ARF benefit may be subject to quarterly or half yearly audit by the third party auditors, to ensure the status of compliance of the set standards and enforcement of the configured regulations, which also kept the control over the malpractices in law enforcement as mentioned in UNEP 2009 report, and makes the system more transparent.

\section{Conclusions}

The paper proposed a national uniform E-waste management system for India based on the current, social, economical, occupational and environmental scenario, needs and requirements analysis in light of various successful practices, approaches followed in various countries, especially the best practice of Switzerland. The proposed system may lead to more formal and rigorous control of the regulatory authority over the E-waste collectors, traders, recyclers, manufactures and importers-exporters of electronic appliances. It may intensify the E-waste collection and lead to more appropriate use of resources including technical expertise and technologies for better E-waste management. The Indian E-waste system requires several reforms for the environmentally sound and regulated scientific processing of Ewaste. Further, studies, considerations and research are required for reforming the policies, legislature and laws related to E-waste to suit the Indian scenario. Also there exists a need for finding out the most environmental friendly recycling/disposal processes and treatment options for handling the E-waste containing the various toxic and hazardous materials. Management of E-waste, if properly carried out, is an opportunity as it is often called as "urban mining." The role of public private partnership (PPP) plays a key role in developing and organizing a sound E-waste management strategy in India. Although very few private enterprises have established the facilities for the E- 


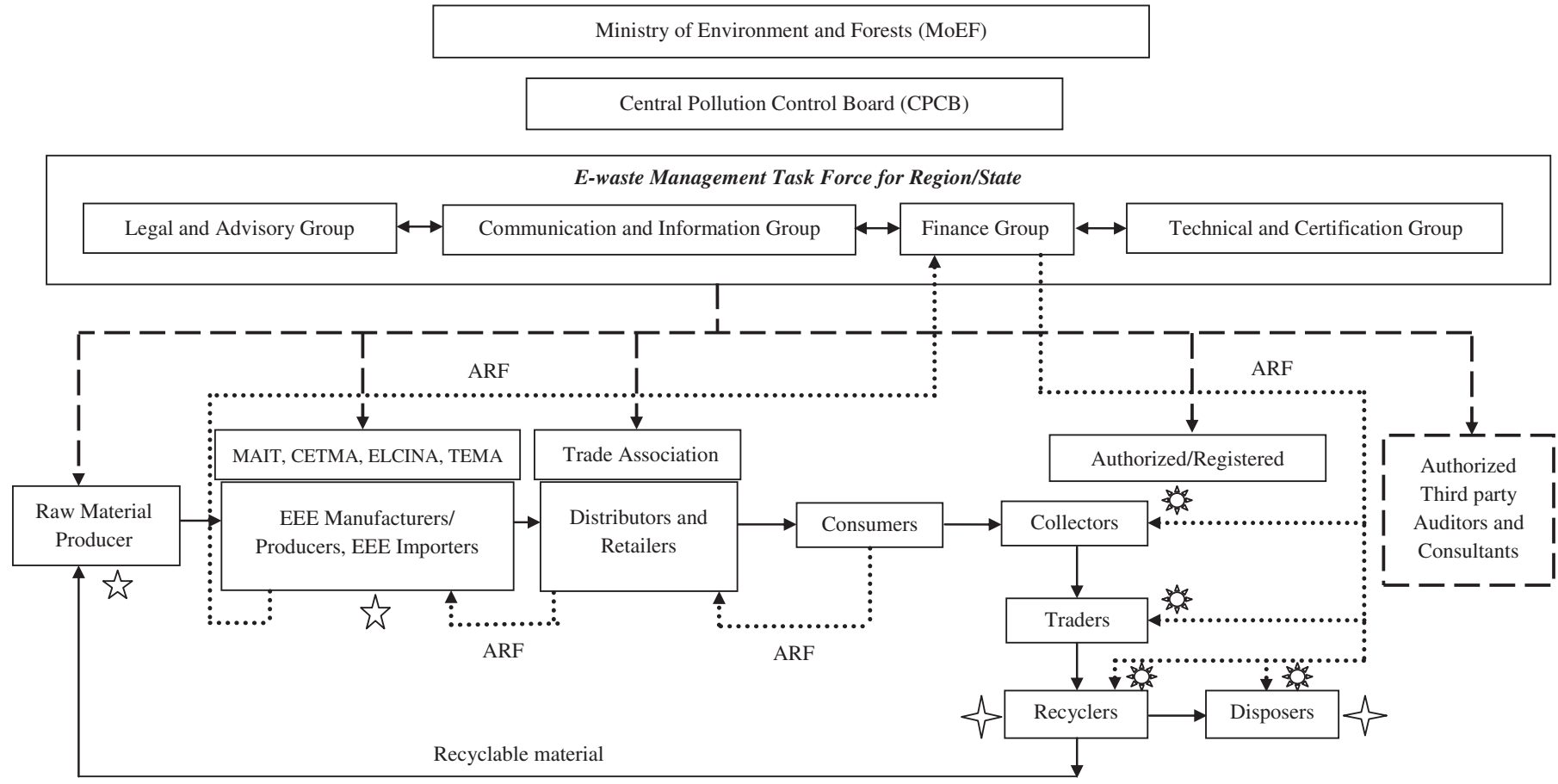

Fig. 5. Proposed E-waste management system for India. of Eco-design. task force. ARF, Advance Recycling Fee (based on the principal of Indian Government Provident Fund Scheme). . . . • • • direction of ARF flow. $\longrightarrow$ , registration should be made mandatory (optional for collectors/traders for availing the ARF benefit).

waste treatment in few cities like Bangalore, Chennai, and Noida which are handling and treating the E-waste in more scientific and environmental friendly manner.

\section{References}

Agamuthu P, Khidzir KM, Hamil FS. Drivers of sustainable waste management in Asia. Int J Waste Manage Res 2009:2009(27):625-33.

BAN, 2002. The Basel Action Network (BAN), The Silicon Valley Toxics Coalition (SVTC), Toxics Link India, SCOPE (Pakistan), Greenpeace China. Exporting harm: The hightech trashing of Asia. Seattle, WA, San Jose, CA; February 25, 2002.

Bandyopadhyay A. A regulatory approach for E-waste management: a cross-national review of current practice and policy with an assessment and policy recommendation for the Indian perspective. Int J Environ Waste Manage 2008; vol.2(Nos. 1/2): 139-86.

Baud I, Grafakos S, Hordjik M, Post J. Quality of life and alliance in solid waste management. Cities 2001;18(1):3-12.

Bhamra TA. Eco-design: the search for new strategies in product development. Proc Inst Mech Eng B J Eng Manuf 2004;218:557-69 2004 [London].

Bhuie AK, Ogunseitan OA, Saphores J, Shapiro AA. Environmental and economic tradeoffs in consumer electronic products recycling: a case study of cell phones and computers. proceedings of the 2004 IEEE International Symposium on Electronics and the Environment, IEEE; 2004. p. 74-9.

Chen P. WEEE recycling and legislation development in China. Conference paper, Electronics Goes Green 2004, Berlin; 2004. September 6-8, 2004.

Columbia University. Final report of a workshop in Applied Earth Systems Management II conducted by Master of Public Administration program in Environmental Science and Policy Columbia University - S 510. Electronic Waste Recycling Promotion and Consumer Protection Act; 2006. December, 2006.

Department for Environment, Food and Rural Affairs (DEFRA) Report (March, 2004). $<$ www.defra.gov.uk>.

Electronics Industries Alliance Regulatory Tracking Tool (EIATRACK); 2007. <www. eiatrack.com>.

Empa. E-waste pilot study Delhi: knowledge partnerships with developing and transition countries. St. Gallen Empa; 2004. 2004 <http://www.ewaste.ch/>

European Commission. Draft proposal for a European parliament and council directive on waste electric and electronic equipment, Brussels, 2000, Belgium; 2000. <http://www. eia.org/download/eic/21/www_Final_Proposal_June_2000.htm>, 2000-07-31.

EU. European Union, 2002, WEEE Directive; 2002. (EU, 2002a).

EU. European Union Waste Electrical and Electronic Equipment (WEEE) Directive; 2003 (EU, 2003a).
Gottberg A, Morris J, Pollard S, Mark-Herbert C, Cook M. Producer responsibility, waste minimisation and the WEEE Directive: case studies in eco-design from the European lighting sector. J Sci Total Environ 2005;359(2006):38-56.

Gregory J, Kirchain A. A comparison of North American electronic recycling systems. Proceedings of the 2007 IEEE international symposium on electronics and the environment, IEEE; 2007. p. 227-32. 2007.

GTZ-MAIT. A study on E-waste assessment in the country. The German Technical Cooperation Agency (GTZ) and Manufacturer's Association for Information Technology Industry (MAIT) press release on date December 13, $2007<\mathrm{http}$ :// www.mait.com/admin/press images/press77-try.htm>.

Gullet BK, Gullet, Linak WP, Touati A, Wasson SJ, Gatica S, King CJ. Characterization of air emissions and residual ash from open burning of electronic wastes during simulated rudimentary recycling operations. J Mater Cycles Waste Manage 2007;9:69-79.

Guo D, Wu Y, Yu H, Ge W, editors. The impact of EU environmental requirements on China (Draft). State Environmental Protection Administration. Policy Research Centre for Environment and Economy and Deutsche gesellschaft fur technische zusammenarbeit (GTZ) GmbH; 2005. 2005.

Haque A, Mujtaba I, Bell J. A simple model for complex waste recycling scenarios in developing countries. Waste Manage 2000;20:625-31.

Heimbuch J. An article entitled India Struggling with Nearly Half a Million Tons of eWaste..and Growing, 2009. Published on date March 11, 2009. <http://www. treehugger.com/files/2009/11/india-struggling-with-nearly-half-a-million-tonsof-e-waste-and-growing.php>.

Hicks C, Dietmar R, Eugster M. The recycling and disposal of electrical and electronic waste in China - legislative and market responses. J Environ Impact Assess Rev 2005;25:459-71.

Hischier R, Wager P, Gauglhofer J. Does WEEE recycling make sense from an environmental perspective? The environmental impacts of the Swiss take-back and recycling systems for waste electrical and electronic equipment (WEEE). Environ Impact Assess Rev 2005;25(2005):525-39.

IRGSSA. International Resource Group, Delhi. Country level WEEE assessment study by IRGSSA 2005; 2005.

Karla V. An article UNEP recognises the e-waste problem in Asia-Pacific, 2004, published on June 26, 2004. <http://www.toxicslink.org/art-view.php?id=34>.

Khetriwal DS, Kraeuchi P, Widmer R. Producer responsibility for E-waste management: key issues for consideration - learning from the Swiss experience. J Environ Manage 2009;90(1):153-65.

Khetriwal DS, Kraeuchi P, Schwaninger M. A comparison of electronic waste recycling in Switzerland and in India. J Environ Impact Assess Rev 2005;25:492-504.

Kimberley M. An article E-waste in India: A Growing Industry and Environmental Threat, 2007. Published on September 10, 2007. <http://www.treehugger.com/ files/2007 /10/e-waste_in_india.php>. 
Lewis H, Gertsakis J. Design and environment. Sheffield. Greenleaf Publishing; 2001 2001.

Lindhqvist T. Extended Producer Responsibility (EPR) in cleaner production. Lund University, Lund, Sweden: The International Institute for Industrial Environmental Economics; 2000. 2000.

MAIT, 2008-2009. Manufacturer's Association for Information Technology Industry (MAIT) performance Annual Review 2008-2009. <http://www.mait.com>.

Manomaivibool P. Extended producer responsibility in a non-OECD context: the management of waste electrical and electronic equipment in India. Resour Conserv Recycl 2009;53(3):136-44 January 2009.

MoEF. Guidelines for Environmentally Sound Management of E-waste (as approved vide Ministry of Environment and Forests (MoEF) letter No. 23-23/2007-HSMD; 2008. dated March 12, 2008.

MPCB. Report on assessment of electronic wastes in Mumbai-Pune area by Maharashtra State Pollution Control Board (MPCB); 2007. March, 2007.

Mundada M, Kumar S, Shekdar A. E-waste: a new challenge for waste management in India. Environ Stud 2003;61(3):265-79.

NCAER. National Council of Applied Economic Research (NCAER), India; 2007. <www. ncaer.org $>$.

NDRC. P. R. C. National Development and Reform Commission (NDRC). Ordinance on the management of waste household electrical and electronic products recycling and disposal (draft). NDRC Express; 2004. September 19, 2004.

OECD. Extended producer responsibility; a guidance manual for governments: Organization of Economic Co-operation and Development (OECD); 2001.2001.

Peralta G, Peralta GL, Fontanos PM. E-waste issues and measures in the Philippines. Proceedings of The Third Workshop on Material Cycles and Waste Management in Asia (NIES E-waste workshop). Tsukuba, Japan: NIES; 2004. December 14-15, 2004

Persson JB. Eco-indicators in product development. Proc Inst Mech Eng B J Eng Manuf 2001;215(5):267-75 2001

Puckett J, Byster L, Westervelt S, Gutierrez R, Davis S, Hussain A, Dutta M. A report exporting harm the high-tech trashing of Asia; 2002. February 25, $2002<\mathrm{http}$ :// ban.org/E-waste/technotrashfinalcomp.pdf>.

Ramzy K, Junbeum K, Ming X, Braden A, Eric W, Peng Z. Exploring E-waste managemen systems in the United States. J Resour Conserv Recycling 2008·52(2008):955-64.

Roy R. Sustainable product service systems. Futures 2000;32:289-99.

SAEFL. Ordinance on the return, take-back and disposal of electrical and electroni equipment. Adopted on 14 January 1998, Entry into force 1 July 1998. <http:// www.umwelt-schweiz.ch/imperia/md/content/abfall/vreg_e.pdf>.

SEPA. P.R.C. State Environmental Protection Agency (SEPA). Notice on strengthening the environmental management of WEEE; 2005. 2003. <http://www.sepa.gov.cn/ eic/649086798147878912/20031017/1042127.shtml> [access date: April 12, 2005].

SEPA. P.R.C. State Environmental Protection Administration (SEPA). Notice on the environmental management situation of waste electric and electronic products; 2004. <http://www.crra.com.cn/hykx(36).htm> [access date: October 25th, 2004]

SEPA. P.R.C. State Environmental Protection Agency (SEPA). Notification on the import of the seventh category of wastes. SEPA document; 2000. 19/2000, 2000.

SEPA. P.R.C. State Environmental Protection Administration (SEPA). Law on the prevention of environmental pollution from solid waste. PRC Presidential Order, No. 58; 1995. October 30, 1995.
Sherwin C. Innovative eco-design. An exploratory and descriptive study of industria design practice. PhD thesis, School of Industrial and Manufacturing Science, Cranfield University,2000.

Silicon Valley Toxic Coalition (SVTC). Just say no to E-waste: background document on hazards and waste from computers; 2006. 2003 <http://www.svtc.org/cleancc/ pubs/sayno.htm>, 2003-01-06.

Sinha-Khetriwal D, Widmer R, Schluep M, Eugster M, Wang X, Lombard R, Ecroignard L. Legislating e-waste management: progress from various countries. Journal of Environmental Law Network International (elni) review 2006;1+2/06:27-36.

Srinivasan S, Bhambri V. Article on 'Environmentalists seek new law on E-waste recycling; 2009. dated June 5, 2009 <http://www.indiaenews.com/technology/ 20090605/201797.htm>.

Terazono A, Murakami S, Abe N, Inanc B, Moriguchi Y, Sakai S, Kojima M, Yoshida A, Li J, Yang J, Wong MH, Jain A, Kim I, Peralta GL, Lin CC, Mungcharoen T, Williams E. Current status and research on E-waste issues in Asia. J Mater Cycles Waste Manage 2006;8(1):1-12 2006

The Economist. Recycling old computers, The Economist, 29.01.2005 (2005), 56 London; 2005.

TRAI. Telecom Regulatory Authority of India annual report 2007-08; 2007. <www.trai. gov.in>.

Toxic Link. Scrapping the hi-tech myth; computer waste in India; 2003. February 1 $2003<$ http://www.toxicslink.org/pub-view.php?pubnum=37>

Toxics Link. Is India becoming dumping ground for British e-waste?; 2004. $2004<$ http: / www.toxicslink.org/mediapr-view.php?pressrelnum $=5>$.

Turner M, Callaghan D. Waste electrical and electronic equipment directive, UK to finally implement the WEE Directive. Comput Law Secur Rep 2007;23:73-6.

UNEP. Developing integrated solid waste management plan training manual-volume 2: assessment of current waste management system and gaps therein. United Nations Environment Programme (UNEP); 2009. 2009. <http://www.unep.or.jp/ ietc/Publications/spc/ISWMPlan_Vol2.pdf>.

UNEP. A report - recycling - from E-waste to resources, 2010. Released by United Nations Environment Programme (UNEP); 2010 on date February 22, 1010.

Van Hemel C, Cramer J. Barriers and stimuli for eco-design in SMEs. J Clean Prod 2002;10(5):439-53 2002

Van Hemel C.,G., 1998. Eco-design empirically explored. Design for environment in Dutch small and medium sized enterprises. PhD thesis. PhD thesis, Design for Sustainability Research Programme, Delft University of Technology, 1998.

Wath SB, Dutt PS, Chakrabarti T. E-waste scenario in India, its management and implications. J Environ Monit Assess 2010. doi:10.1007/s10661-010-1331-9.

Widmer R, Oswald-Krapf H, Sinha-Khetriwal S. Global perspectives on E-waste. J Environ Impact Assess Rev 2005;25(5):436-58 2005.

Wilson DC. Development drivers for waste management. Waste Manage Res 2007;25: 198-207.

Williams E, Ramzy K, Allenby B, Kavazanjian E, Xu M, Kim J. Environmental, social and economic implications of global reuse and recycling of personal computers. Int J Environ Sci Technol 2008;42(17):6446-54. 